Journal of Contemporary Educational Research

Research Article

\title{
Problems in College English Teaching from the Perspective of College English Teachers and Their Coping Strategies
}

Fuhua Liu

School of Foreign Languages, Dalian Jiaotong University, Dalian 116028, Liaoning Province, China

\begin{abstract}
The present paper is an analysis of problems in college English teaching from the perspective college English teachers and their coping strategies. The four major problems concerning vocabulary-oriented teaching method, collective lesson preparation, on-line and off-line resources and college English teachers' comprehensive abilities are introduced and analyzed and corresponding coping strategies are offered.
\end{abstract}

Key words: Problems; College English teaching; College English teachers; Coping strategies

Publication date: October, 2020

Publication online: 31 October, 2020

*Corresponding author: Fuhua Liu, taolichengxi@126. com

\section{Introduction}

As the reform of college English courses deepens, college English teachers continue to explore new ways of solving various problems emerging in the reforming process. While some problems have been in existence for quite a long time, others are new ones that arise from the advancement in technology and educational reform. The present paper tries to introduce some major problems in college English teaching from the perspective of college English teachers and offers corresponding coping strategies in a bid to teach students in a more sensible and scientific manner in the future.

\section{Problem of "Voc abulary" and its Coping Strategies}

The first problem in some college English teachers' language teaching is that they tend to focus on vocabulary, which has become an outdated way of teaching. In class, they elaborate on the word list offered in students' textbooks by explaining the connotations of all the words in detail and making up sentences with them. After class, they ask students to write down all the new words and their Chinese equivalents as part of their homework assignments. In the final examination, they check students' mastery of vocabulary through multiple choice question types. It seems as if students' English proficiency is mostly dependent on the mastery of English vocabulary. There is no denying the fact that English vocabulary, which lays the foundation of language learning, is of vital importance, but too much emphasis on it only undermines students' language learning abilities in a comprehensive manner.

To solve the problem, students should be encouraged to memorize and use words at least in a sentence if not in a paragraph, as language learning ought to be sentence-based rather than word-based. Students should not be restricted to the memorization of words only. Instead, they should read extensively, listen and speak often, and write on a regular basis, all of which are paragraph or passage-based rather than wordbased. Students will benefit from learning English in a comprehensive manner if they strive to handle a paragraph or passage rather than a single word.

\section{Problem of "Collective Lesson Preparation" and its Coping Strategies}

Some colleges underestimate the importance of collective lesson preparation for college English teachers, and many college English teachers prefer 
to prepare their lessons individually. Although most colleges across the country have carried out collective lesson preparation, they tend to make it a "form" which lacks "effectiveness" and "quality" ${ }^{\text {"[] }}$. The following are some major problems that may arise from collective lesson preparation for college English teachers. First, in some schools, some teachers attend the group activity without any reservations or questions, which leads to the embarrassing situation in which teachers may just sit together in one room and prepare their lessons on their own without any interaction or discussion. In addition, after the meeting, college English teachers in some schools fail to come up with detailed teaching schedules as to how to teach so that they can share in their coming teaching practice.

To solve the above problems, teachers should start with adopting positive attitudes towards collective lesson preparation. Teachers should get ready academically before they are present for the collective lesson preparation activities. That is, they should attend the group activity with a prepared mind of ideas and questions so that they can communicate, discuss or even debate while preparing their lessons collectively and together solve the problems that they have encountered in their teaching practice.

What is more important, college English teachers should come up with detailed teaching plans as to how to teach concerning a certain unit. For example, to deal with the speaking part of Unit 2 of the College English Listening and Speaking Book 1 compiled by Chen Xiangjing, college English teachers may work together to design suitable speaking activities for their students. The following serves as a good example of how collective lesson preparation with my colleagues produces a detailed teaching schedule for a specific speaking task. After much discussion of unit 2, we decide to ask students to play the roles of a newly married couple and to start a conversation on whether to have a baby or not. The choice of such a topic is appropriate in that students can experience a married life in advance and thus become mentally prepared for having and raising a baby in the future. We also reach the following conclusion: In order to offer students the opportunity to enhance what they have learned in this unit, we require students to use the information that they have just learned in the "news reports" and "functional language" available in this unit. Therefore, information from the news reports that can well support their arguments and functional language that well fits the dialogue are provided for our students. The piece of information "Parents can expect to spend around $\$ 365,000$ on raising a child from birth to the age of $21 .{ }^{\text {"[2] }}$ can be used as solid evidence to show one' opposition to having a baby. And the functional language "That's so disappointing ${ }^{[2]}$." can be used to show one's frustration when hearing the other speaker's opposition. Subsequently, with joint efforts, we come up with some scaffolds for students' reference. Through these group activities, our teaching abilities are greatly enhanced.

\section{Problem of "Online and Offline Resources" and its Coping strategies}

Some colleges retain books that do not advance with the times. For example, "News Reports" have been added to the listening comprehension part of CET 4, but some schools continue to use books that contain no news reports, which is obviously against the trend. Therefore, these schools should use books that show consistence with the national requirements. Another problem is that there is a sharp increase of students' textbooks and teachers' reference books that college English teachers can choose from. However, the emergence of a wealth of book resources all at once sometimes tends to confuse teachers who can be easily overwhelmed with so many choices available. Based on the law of language learning, students should deal with all the books available if time permits, because the more they learn, the more qualified language learners they will become. But the real situation is that students have to deal with several other subjects besides English, which urges teachers to choose the best out of the best.

There are some defects in virtually all the textbooks and reference books in that they follow the same model of original texts and exercises for students' textbooks and sentence makeup for key vocabulary and text structure analysis for teachers' reference books. With the development of technology, students never lack the original texts and sentence makeup for words as they can find all the materials available online. In other words, from the perspective of teachers, they do not lack "what to teach", but "how to teach" ${ }^{[3]}$. Therefore, students' textbooks and teachers' reference books should be further reformed and should finally be transformed to books containing the details of "how to learn" and "how to teach".

The major problem of online resources for students' textbooks is that they are still technically immature. For 
example, some teachers find it rather difficult to use a certain app to assign homework or to give a test, just because the app is not that user-friendly. Also, most of the apps are not intelligent enough to take the place of human labor. For example, the u-campus app fails to judge whether students' pronunciation is accurate enough or not. So even a student pronounces a certain word inaccurately, the app still gives him or her a high score. Besides, college English teachers are bombarded with too many apps, so many so that they tend to hinder their normal teaching. Therefore, we have to wait for a future in which technology advances, matures and functions as a real assistant for college English teachers. We also expect one super app to stand out so that we do not have to use all the apps all at once.

\section{Problem of "College English Teachers' Comprehensive Abilities" and its Coping Strategies}

To be qualified college English teachers, language abilities are the basic qualities needed. Apart from language abilities, college English teachers need to possess many other qualities such as having a wide range of knowledge and being able to express it freely in English, administrative abilities and a good command of technology. Many college English teachers, especially senior ones, obviously lack or fail to excel in one or some of the required qualities. The solution to the above problems is to give college English teachers the opportunities to be trained. At the same time, various ways must be thought out to motivate college English teachers to develop lifelong learning attitudes.

\section{Conclusion}

The present paper explores some major problems in college English teaching and offers coping strategies as to what college English teachers can do to solve these problems. There are generally four major problems introduced. The first problem prevalent among college English teachers is the vocabulary-centered teaching method which hampers students' comprehensive learning of English language. The solution to this problem is to change the vocabulary-centered teaching method to sentence or paragraph or even passagecentered method. The second problem is about college English teachers' collective lesson preparation. A lack of collective lesson preparation of some colleges and inappropriate practices concerning it are introduced and the solution is to require teachers to come with prepared minds and to end with specific teaching schedules on how to teach a certain unit. The third problem is about the resources both off line and on line. Offline book resources should focus on how to teach instead of what to teach, while online resources should be improved in terms of technology. The last problem concerns college English teachers' comprehensive qualities. Apart from language abilities, college English teachers need to cultivate their other abilities, get the needed training and develop lifelong learning attitudes. By analyzing these four major problems and offering corresponding coping strategies, teachers can better understand the law of language teaching so that they can be more qualified in the future.

\section{References}

[1] Lin YJ. Major Problems in Collective Lesson Preparation and Coping Strategies[J]. New Education Era, 2020(2).

[2] Chen XJ. College English Listening and Speaking[M]. Foreign Language Teaching and Research Press, 2017(8).

[3] Liu FH. A Critical Evaluation on College English Reference Books for Teachers[J]. Overseas English. 2013(19). 